\title{
Quality of cucumber seedlings grown in different containers
}

\author{
Bruna Finotii Fonseca Reis de Mello ${ }^{1}$, Mateus Vieira Trevisan ${ }^{1}$, Fábio Steiner ${ }^{1}$ \\ 1 Universidade Estadual de Mato Grosso do Sul, Unidade Universitária de Cassilândia, Cassilândia, Mato Grosso do Sul, Brasil. \\ E-mail: anjabruninha@hotmail.com, mateus_mvt@hotmail.com, steiner@uems.br
}

Recebido: 29/12/2015; Aceito: 29/03/2016.

\begin{abstract}
The use of high quality seedlings is a key factor for the success of vegetable production, and the container size and design characteristics of the containers are important determinants of seedling quality. A experiment was conducted to investigate the effects of different container types on quality of cucumber seedlings (Cucumis sativus L., cv. Aodai Melhorado). Seedlings were grown in a seedling nursery with shadow protection at $50 \%$ in different containers: (i) 128-cell trays; (ii) 64-cell trays; (iii) tubes of $120 \mathrm{~cm}^{3}$; and (iv) plastic cups of $180 \mathrm{~cm}^{3}$. The plant height, diameter, root length, shoot dry matter, root dry matter, sturdiness quotient (SQ), shoot:root dry matter ratio (SRR) and Dickson quality index (DQI) were measured at $21^{\text {st }}$ days after sowing. The production of cucumber seedlings in 64-cell trays, polypropylene tubes of $120 \mathrm{~cm}^{3}$ and plastic cups of $180 \mathrm{~cm} 3$ resulted in the highest values for the majority of investigated traits. The tray of 128-cells results in lower quality cucumber seedlings compared to other containers. Tubes with volume of $120 \mathrm{~cm}^{3}$ and plastic cups with volume of $180 \mathrm{~cm}^{3}$ are more appropriate containers for the production of high quality cucumber seedlings. The DQI is a good indicator of the standard of quality of cucumber seedlings.
\end{abstract}

Key words: Cucumis sativus L, trays, tubes, cups, seedling quality.

\section{Qualidade de mudas de pepino produzidas em diferentes recipientes}

\section{RESUMO}

O uso de mudas de alta qualidade é um dos principais fatores para o sucesso da produção de hortaliças. O tipo e o tamanho dos recipientes são determinantes para a obtenção de mudas de qualidade. Um experimento foi conduzido para avaliar os efeitos de diferentes recipientes na qualidade de mudas de pepino cv. Aodai Melhorado. As mudas foram cultivadas em um telado com sombrite a 50\% em diferentes recipientes: (i) bandejas de 128-células; (ii) bandejas de 64-células; (iii) tubetes de $120 \mathrm{~cm}^{3}$; e (iv) copos plásticos de $180 \mathrm{~cm}^{3}$. Aos 21 dias foram mensurados altura, diâmetro, comprimento das raízes, matéria seca da parte aérea e das das raízes, quociente de robustes, relação de matéria seca da parte áerea: raízes e o índice de qualidade de Dickson (IQD). Os resultados indicaram que a produção de mudas de pepino em bandejas de 64-células, tubetes de $120 \mathrm{~cm}^{3}$ e copos plásticos de $180 \mathrm{~cm}^{3}$ resultou em maiores valores para a maioria das variáveis mensuradas. A bandeja de 128-células resultou em mudas de pepino com qualidade inferior às mudas produzidas nos demais recipientes. Os tubetes de $120 \mathrm{~cm}^{3} \mathrm{e} \mathrm{copos}$ plásticos de $180 \mathrm{~cm}^{3}$ são os recipientes mais adequados para a produção de mudas de pepino. O IQD foi um bom indicador do padrão de qualidade das mudas de pepino.

Palavras-chave: Cucumis sativus L, trays, tubes, cups, seedling quality. 


\section{Introduction}

Cucumber (Cucumis sativus L.) is a warm season, vining, annual plant in the family Cucurbitaceae grown for its edible cucumber fruit (FILGUEIRA, 2008). Fruits of the cultivar Aodai (group salad) have smooth skin with few spines and glossy dark green color; they are cylindrical, approximately 20 to $25 \mathrm{~cm}$ long and 4.5 to $5.0 \mathrm{~cm}$ in diameter, with average weight of $350-400 \mathrm{~g}$ (FILGUEIRA, 2008). The cucumber is the second most produced cucurbit worldwide after the watermelon (Citrullus lanatus - Cucurbitaceae) (CARVALHO et al., 2013). In Brazil, the cucumber is the fourth most widely cultivated vegetable, with mean annual production around 220,000 tons in 2013 (CARVALHO et al., 2013).

The quality of seedlings used is a major factor that determines the success of cucumber production. This is because the cucumber seedlings do not transplant well due to their root systems do not tolerate or recover well from any damage (FILGUEIRA, 2008). During the seedling production phase, container size, growing density and design characteristics of the containers are important determinants of seedling quality (LANDIS et al., 1990).

Different types of recipients are used for seedling production (test tubes, trays, plastic bags), made from different materials (including expanded polystyrene, polypropylene) and sizes, especially expanded polystyrene trays that are the most used for cucumber seedling production (FILGUEIRA, 2008). The volume of the cavity is one of the most obvious and important characteristics of a container because in general, the larger the container the larger the seedling that can be produced (ECHER et al., 2007; COSTA et al., 2012; 2013). However, the optimum container size varies according to many different factors, including species, growing density, environmental conditions and length of the growing season (TSAKALDIMI et al., 2005).

Many studies with different species have been carried out with the objective of producing high quality seedlings (RESENDE et al., 2003; ECHER et al., 2007; RODRIGUES et al., 2010; COSTA et al., 2009; 20012; 2013), and the results have shown that larger containers have allowed the seedlings to grow and develop better. Costa et al. (2013) recommended 72-cells trays for the production of better quality eggplant seedlings (Solanum melongena - Solanaceae). The tray of 72-cells was also better container for the production of tomato seedlings (Solanum lycopersicum - Solanaceae) (RODRIGUES et al., 2010). Echer et al. (2007) reported that the better container for production of beet seedlings (Beta vulgaris - Chenopodiaceae) is the 128-cell expanded polystyrene trays. However, the effects of container types and sizes on quality of cucumber seedlings are still incipient and inconclusive.
This research was carried out to investigate the effects of different container types on quality of cucumber seedlings (Cucumis sativus L., cv. Aodai Melhorado).

\section{Material e Methods}

The experiment was conducted in a seedling nursery at the Horticultural Department of the Mato Grosso do Sul State University (UEMS), in Cassilândia, Mato Grosso do Sul, Brazil (1905'20" S, 51 $48^{\prime} 24^{\prime \prime} \mathrm{W}$, and altitude of $470 \mathrm{~m}$ ). Cucumber seeds of the cultivar 'Aodai melhorado' were planted on October $22^{\text {th }}, 2015$, in 128-cell expanded polystyrene trays with a volume of $30 \mathrm{~cm}^{3}$ per cell (container standard for producing cucumber seedlings); 64-cell expanded polystyrene trays with a volume of $60 \mathrm{~cm}^{3}$ per cell; black polypropylene tubes with volume of $120 \mathrm{~cm}^{3}$; and plastic cups with volume of $180 \mathrm{~cm}^{3}$. All containers were filled with commercial substrate composed of coconut fiber (Bioplant ${ }^{\circledR}$ ). Two seeds were sown per cell or container, and five days after sowing, they were thinned to one seedling per cell or container. Cucumber seedlings were grown in a seedling nursery with shadow protection at $50 \%$. The experimental was arranged in a randomized complete block design with four treatments (four container types) and ten repetitions.

Cucumber seedlings were evaluated at 21 days after sowing. Seedlings in all treatments were removed from the containers and washed with water to remove substrate adhered to the roots. Posteriorly, the seedlings were separated into roots and shoots, dried in a forced air circulation oven for three days at $65^{\circ} \mathrm{C}$, and then weighed. The results of shoot dry matter (SDM) and root dry matter (RDM) were expressed in grams per seedling. The shoot length (SL, in $\mathrm{cm}$ ) and root length $(\mathrm{RL}$, in $\mathrm{cm})$ were measured using meter scale $(\mathrm{cm})$. Root volume ( $\mathrm{RV}$, in $\mathrm{cm}^{3}$ seedling ${ }^{-1}$ ) was determined by water displacement using a calibrated cylinder. Collar diameter $(\mathrm{CD}$, in $\mathrm{mm})$ was measured by using a digital caliper with accuracy of $0.01 \mathrm{~mm}$. From these measurements were calculated total dry matter (TDM), shoot:root dry matter ratio [SRR; shoot dry matter $(\mathrm{g}) /$ root dry matter $(\mathrm{g})$ ], sturdiness quotient [SQ; shoot length $(\mathrm{cm}) /$ collar diameter $(\mathrm{mm})]$ and Dickson Quality Index $[D Q I=\mathrm{TDM} /(\mathrm{SRR}+\mathrm{SQ}]$ (DICKSON et al., 1960).

The normality of data was previously tested by the Kolmogorov-Smirnov test and then data were submitted to analysis of variance (ANOVA), and means of treatments were compared by the Tukey test at the 0.05 level of confidence. All analyses were performed using Sisvar version 5.3 software for Windows (Statistical Analysis Software, UFLA, Lavras, MG, BRA). 


\section{Results and Discussion}

The container types significantly affected $(\mathrm{P} \leq 0.05)$ on all the measured traits (Figures 1 and 2). The greater shoot height of cucumber seedlings $(10.3 \mathrm{~cm})$ was obtained with the polypropylene tubes of $120 \mathrm{~cm}^{3}$, followed by 64-cell trays $(9.1 \mathrm{~cm})$ and plastic cups of $180 \mathrm{~cm}^{3}(8.1 \mathrm{~cm})$ (Figure 1A). Smiderle et al. (2001) evaluating different substrates found that the height of cucumber seedlings at 21 days after sowing range from 6.5 to $14.2 \mathrm{~cm}$. In this study, only the cucumber seedlings produced in 128-cells trays showed lower shoot height $(5.7 \mathrm{~cm})$ to those values reported by Smiderle et al. (2001).

The greater length of roots $(21.0 \mathrm{~cm})$ was obtained with the use of polypropylene tubes (Figure 1B). The length of cucumber roots produced in plastics cups and 64-cells trays were 17.4 and $17.0 \mathrm{~cm}$, respectively. These values are higher than those reported by Smiderle et al. (2001), who found that the root length of cucumber seedlings at 21 days ranged from 23.3 to $14.4 \mathrm{~cm}$.

The 64-cell trays, polypropylene tubes and plastic cups resulted in cucumber seedlings with the highest values of stem diameter ( 3.22 to $3.85 \mathrm{~mm}$ ). In the tray of 128-cell the collar diameter was $2.1 \mathrm{~mm}$ (Figure 1C).
The increase in stem diameter is important for providing greater robustness to the seedlings. The stem diameter has been appointed as the best and most practical characteristics for classification and identification of high quality seedlings, and therefore can be considered a good predictor of outplanting survival. Ivetić et al. (2013) reported that stem diameter was the most important grading characteristic, followed by root volume and shoot height.

The largest root volume (22.6 to $24.0 \mathrm{~cm}^{3}$ seedling 1) was obtained for the seedlings produced in 64-cell trays, polypropylene tubes and plastic cups (Figure 1D). Root volume is an important indicator of survival in the field (IVETIĆ et al., 2013). Restrictions to root growth may reduce the ability of seedlings to maintain adequate xylem water potential, termed drought avoidance, during the critical establishment period following outplanting (NESMITH; DUVAL, 1998). Studies on production of nursery seedlings indicate that a high quality seedling should have an average root volume of 20 to $35 \mathrm{~cm}^{3}$. Therefore, based on this inference only the root volume of seedlings produced in 128-cell trays cannot be classified as high quality.

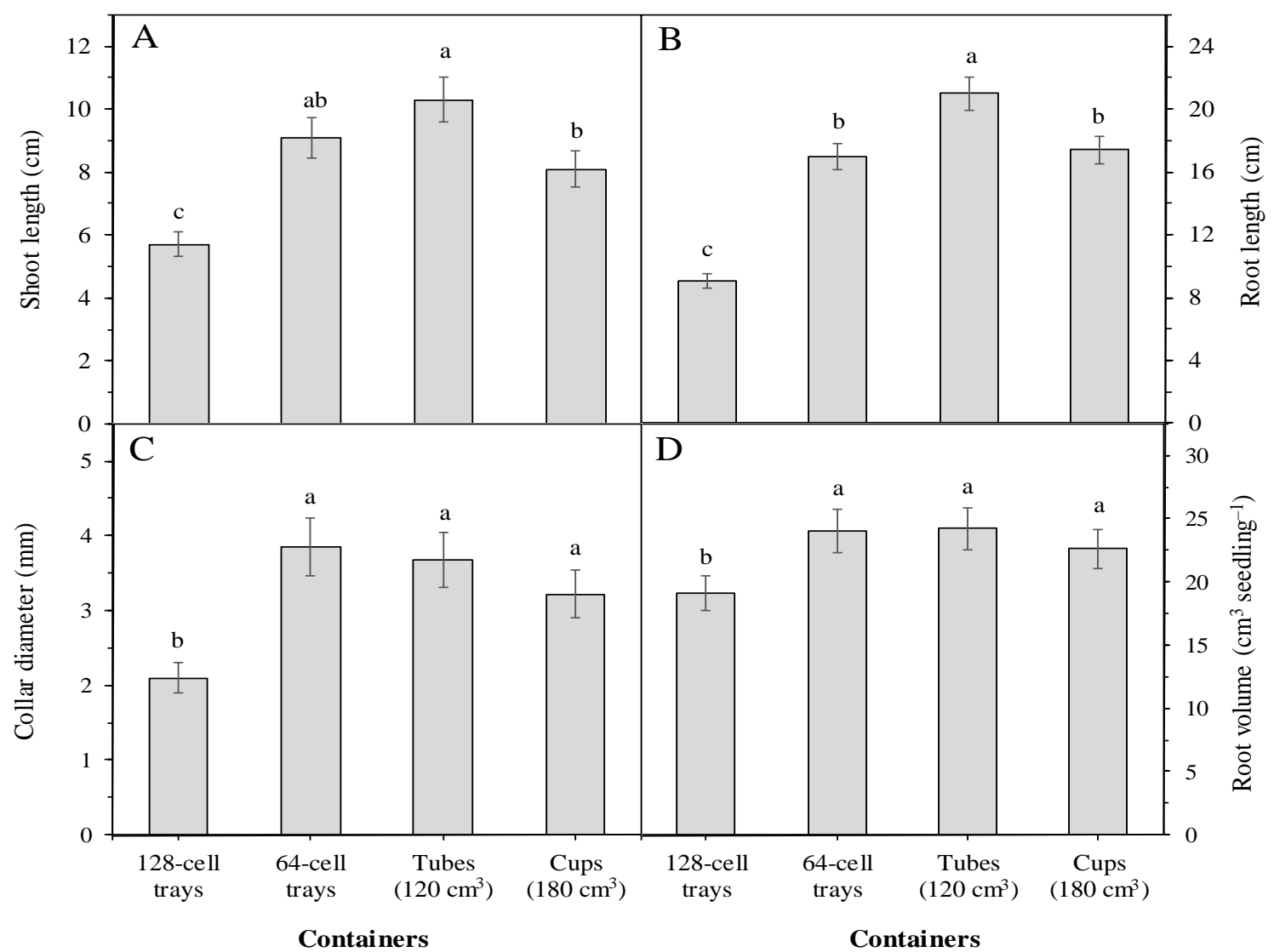

Figure 1. Effects of container types on shoot length (SL, in A), root length (RL, in B), collar diameter (CD, in C), and root volume (RV, in D) of cucumber seedlings (Cucumis sativus L., cv. Aodai Melhorado). Bars followed by the same lower case letters are not significantly different by Tukey test at the 0.05 level of confidence. Data refer to mean values $(\mathrm{n}=10) \pm$ standard error. 
The 64-cell trays, polypropylene tubes and plastic cups resulted in cucumber seedlings with the highest values of shoot dry matter ( 0.155 to $0.174 \mathrm{~g}$ seedling $^{-1}$ ) (Figure 2A). The polypropylene tubes and plastic cups provided higher root dry matter (Figure 2B), which resulted in lower shoot:root dry matter ratio (SRR) (Figure 2D). These results indicate that there was a higher photoassimilate partition from shoot to the roots of seedlings produced in polypropylene tubes and plastic cups. The higher total dry matter was also obtained with polypropylene tubes and plastic cups
(Figure 2C). Luqui et al. (2015) also found that 64-cell trays resulted in cucumber seedlings of better quality.

The different containers not significantly affect $(\mathrm{P}>$ 0.05) the sturdiness quotient (shoot length/collar diameter ratio) of cucumber seedlings (Figure $2 \mathrm{E}$ ). The sturdiness quotient of cucumber seedlings ranged from 2.4 to 2.8 . In general, studies on production of nursery seedlings indicate that a high quality seedling should have a value of sturdiness quotient ranging from 2.5 to 3.5 , and a sturdiness quotient greater than 4.0 can be indicative of etiolating of seedlings.

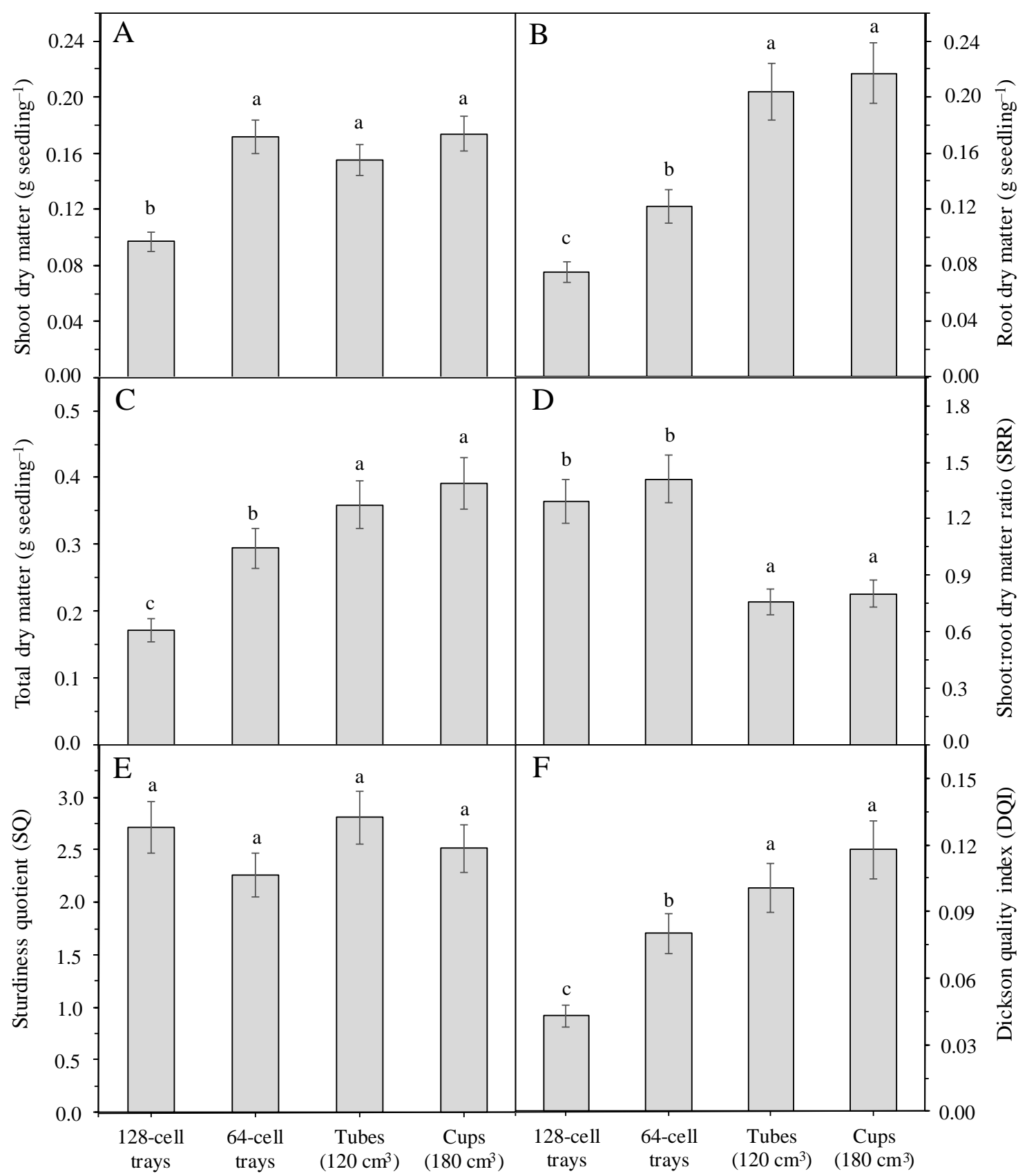

Containers

Containers

Figure 2. Effects of container types on shoot dry matter (SDM, in A), root dry matter (RDM, in B), total dry matter (TDM, in C), shoot:root dry matter ratio (SRR, in D), sturdiness quotient (SQ, in E) and Dickson quality index (DQI, in F) of cucumber seedlings (Cucumis sativus L., cv. Aodai Melhorado). Bars followed by the same lower case letters are not significantly different by Tukey test at the 0.05 level of confidence. Data refer to mean values $(n=10) \pm$ standard error. 
The polypropylene tubes and plastic cups resulted in high quality cucumber seedlings, as reported by the higher values of the Dickson quality index (DQI from 0.10 to 0.12 ) (Figure $2 F$ ). The DQI is considered a promising integrated measure of morphological traits (JOHNSON; CLINE, 1991) and thought to be a good indicator of seedling quality as its calculation computes robustness and dry matter distribution while considering several important parameters, such as height, diameter and dry matter (FONSECA et al., 2002). The higher value of DQI, the higher the seedling quality and they are more vigorous when they are transplanted in the field.

In general, the production of cucumber seedlings in 64-cell trays with a volume of $60 \mathrm{~cm}^{3}$ per cell, polypropylene tubes with volume of $120 \mathrm{~cm}^{3}$ and plastic cups with volume of $180 \mathrm{~cm}^{3}$ resulted in the highest values for the majority of investigated traits (Figures 1 and 2). On the other hand, the tray of 128-cells results in lower quality cucumber seedlings compared to other containers (Figures 1 and 2). These results are due to the different volumes of the containers. Uptake of nutrients, water and dry matter production are affected by the restriction of the roots and thus the volume of substrate that is determined by the container size is an important factor for adequate growth of the seedlings. Costa et al. (2012) found that tray of 72 cells was the best container for production of cucumber seedlings, promoting more vigorous plants in substrate with soil and 7 or $14 \%$ organic compound.

The efficiency of larger containers in the production of high quality seedlings has been reported for other vegetable species, such as lettuce (RESENDE et al., 2003), cucumber (COSTA et al., 2009; LUQUI et al., 2015), eggplant (COSTA et al., 2013), beet (ECHER et al., 2007) and tomato (RODRIGUES et al., 2010).

\section{Conclusions}

Polypropylene tubes with volume of $120 \mathrm{~cm}^{3}$ and plastic cups with volume of $180 \mathrm{~cm}^{3}$ are more appropriate containers for the production of high quality cucumber seedlings.

The production of cucumber seedlings in 128-cells trays should not be recommended for the producers of seedlings, because it results in lower quality seedlings.

The sturdiness quotient (SQ) was not a good indicator for the classification of cucumber seedlings at different levels of vigor or quality.

The Dickson quality index (DQI) is a good indicator of the standard of quality of cucumber seedlings.

\section{References}

CARVALHO, A. D. F.; AMARO, G. B.; LOPES, J. F.; VILELA, N. J.; MICHEREFF-FILHO, M.; ANDRADE, R. A cultura do pepino. Brasília-DF: Embrapa Hortaliças, 2013, 18 p. (Circular Técnica, 113).

COSTA, E.; DURANTE, L. G. Y.; SANTOS, A.; FERREIRA, C. R. Production of eggplant from seedlings produced in different environments, containers and substrates. Horticultura Brasileira, Vitória da Conquista-BA, v. 31, n. 1, p. 139-146, 2013.

COSTA, E.; VIEIRA, L. C. R.; LEAL, P. A. M.; JARA, M. C. S.; SILVA, P. N. L. Substrate with Organosuper for cucumber seedlings formation in protected environments and polystyrene trays. Engenharia Agrícola, Jaboticabal-SP, v. 32, n. 2, p. 226-235, 2012.

COSTA, E.; VIEIRA, L. C. R.; RODRIGUES, E. T.; MACHADO, D.; BRAGA, A. B. P.; GOMES, V. A. Ambientes, recipientes e substratos na formação de mudas de pepino híbrido. Agrarian, Dourados-MS, v. 2, n. 4, p. 95-116, 2009.

DICKSON, A.; LEAF, A. L.; HOSNER, J. F. Quality appraisal of white spruce and white pine seedling stock in nurseries. The Forest Chronicle, Mattawa-ON, v. 36, n. 1, p. 10-13, 1960.

ECHER, M. M.; GUIMARÃES, V. F.; ARANDA, A. N.; BOTOLAZZO, E. D.; BRAGA, J. S. Avaliação de mudas de beterraba em função do substrato e do tipo de bandeja. Semina: Ciências Agrárias, Londrina-PR, v. 28, n. 1, p. 4550, 2007.

FILGUEIRA, F. A. R. Novo manual de Olericultura: agrotecnologia moderna na produção e comercialização de hortaliças. Viçosa-MG: UFV. 2008. 421p.

FONSECA, É. P.; VALÉRI, S. V.; MIGLIORANZA, É.; FONSECA, N. A. N.; COUTO, L. Padrão de qualidade de mudas de Trema micrantha (L.) Blume, produzidas sob diferentes períodos de sombreamento. Revista Árvore, Viçosa-MG, v. 26, n. 4, p. 515-523, 2002.

IVETIĆ, V.; DAVORIJA, Z.; VILOTIĆ, D. Relationship between morphological and physiological at - tributes of hop hornbeam seedlings. Bulletin of the Faculty of Forestry, Belgrade-CS, v. 108, n. 1, p. 39-50, 2013.

JOHNSON, J. D.; CLINE, M. L. Seedling quality of Southern pines. In: DURYEA, M. L.; DOUGHERTY, P. M. (Eds.). Forest regeneration manual. Netherlands: Klumer Academic, 1991. p.143-162.

LANDIS, T. D.; TINUS, R. W.; MCDONALD, S.; BARNETT, J. P. The container tree nursery manual. v. 2. Washington-DC: USDA Forest Service. 1990, 88 p.

LUQUI, L. L.; COSTA, E.; ALVES, A. C.; BINOTTI, F. F. S.; CARDOSO, E. D. Mudas de cultivares de pepineiro em diferentes substratos. Revista de Agricultura Neotropical, Cassilândia-MS, v. 2, n. 1, p. 1-9, 2015.

NESMITH, D.S., DUVAL, J.R. The effect of container size. Horticulture and Technology, Charlotte-NC, v. 8, n. 4, p. 0495-498, 1998.

RESENDE, G. M.; YURI, J. E.; MOTA, J. H.; SOUSA, R. J.; FREITAS, A. C.; RODRIGUES-JÚNIOR, J. C. Efeitos de tipos de bandejas e idade de transplantio de mudas sobre o 
desenvolvimento e produtividade da alface americana. Horticultura Brasileira, Brasília-DF, v. 21, n. 4, p. 558-563, 2003.

RODRIGUES, E. T.; LEAL, P. A. M.; COSTA, E.; PAULA, T. S.; GOMES, V. A. Produção de mudas de tomateiro em diferentes substratos e recipientes em ambiente protegido. Horticultura Brasileira, Brasília-DF, v. 28, n. 4, p. 483-488, 2010 .

SMIDERLE, O. J.; SALIBE, A. B.; HAYASHI, A. H.; MINAMI, K. Produção de mudas de alface, pepino e pimentão em substratos combinando areia, solo e Plantmax®. Horticultura Brasileira, Brasília-DF, v. 19, n. 2, p. 253-257, 2001.
TSAKALDIMI, $\quad$ M.; $\quad$ ZAGAS, $\quad$ T.; TSITSONI, T.; GANATSAS, P. Root morphology, stem growth and field performance of seedlings of two Mediterranean evergreen oak species raised in different container types. Plant and Soil, Drodrecht-NL, v. 278, n. 1, p. 85-93, 2005. 